\title{
Subjective assessment of social status and socio-psychological attitudes of student youth
}

\author{
Elena Suroedova, ${ }^{1, *}$ and Yulya Tushnova ${ }^{1}$ \\ ${ }^{1}$ Don State Technical University, 344003, Gagarin Square, 1, Rostov-on-Don, Russian Federation
}

\begin{abstract}
The problem of accompanying talented youth is closely related to the phenomenon of social status, including the individual psychological characteristics of the perception of their own social status. This article examines the quantitative characteristics of the subjective assessment of the real and ideal social status by students of different levels of education, as well as the relationship between socio-psychological attitudes and the semantic space of the social status of student youth. The study involved 169 students aged 16 to 47 years $(\mathrm{M}=20.6, \mathrm{SD}=4.4(56.4 \% \mathrm{men})$. Methods were used: semantic differential, survey - methodology for diagnosing socio-psychological attitudes of personality by Potemkina O.F., World assumptions scale (WAS) R. Janoff-Bulman (adapted and restandardized by Padun M.A., Kotelnikova A.V.); statistical methods. The study established differences in factor Evaluation, factor Potency and factor Activity, real and ideal status of students at different levels of education, differences in the socio-psychological attitudes of students at different levels of education, as well as the relationship of subjective assessment of real and ideal social status with socio-psychological attitudes. Research prospects are aimed at studying the content characteristics of the subjective assessment of the real and ideal social status of student youth.
\end{abstract}

\section{Introduction}

Adolescence and juvinile age are the most important stages of life in the formation of personality, its active life position, professional self-determination, the development of humanity, moral qualities, worldview, beliefs and socio-psychological attitudes, attitudes to themselves and the world. Subjective assessment and attitude to oneself and the surrounding world (social and subject) begin to form in childhood and become the basis for the development of self-awareness and identity, building a life plan and trajectory of selfdevelopment, professional development and citizenship, value-semantic and motivational orientations, etc. Analysis of status studies shows that there are changes in the subjective assessment of social status, beliefs and attitudes of people in different historical periods of society [1]. Such changes can be largely related to global changes in society: the transition from an industrial society to an information society, the integration and disintegration of States, economic crises, political instability, military conflicts and terrorist activity, the

\footnotetext{
* Corresponding author: suroedova@mail.ru
} 
restructuring of the education system, the influence of the media and the Internet on people's minds and views, etc. Therefore, the issue of studying the subjective social status of young people and their socio-psychological attitudes in conditions of instability, variability and unpredictability becomes relevant.

Subjective social status (hereinafter referred to as SSS) refers to a person's perception of their position or rank in relation to others, and for young people, status is usually defined in the context of society or school [2]. Theoretical analysis of studies of subjective social status shows that it is most often considered in such aspects as the relationship of SSS with physical and mental health [2-6], the influence of family economic wealth and well-being on the formation of SSS [1, 7-10], the level of education and training [8, 11-14], professional and labor activity, employment or unemployment $[5,13,15-16]$, age $[3,5,17$, $18]$, national, ethnic [18- 20], racial [20, 21], class [1, 22] and gender [3, 16, 20], valuesemantic sphere [23-25] and motivational sphere [26].

SSS is not a constant and stable element of the individual's consciousness, it is subject to changes and people tend to predict its dynamics in the future. Research by Rahal Danny, Huynh Virginia, and Cold Steve examined perceptions of changes in their social status in the future in students upon graduation. During the period of school and College, students ' subjective social status remains stable, but at the end of school, teenagers note, their social status will change. Thus, teenagers who do not attend College and teenagers from families with low economic income indicated a decrease in social and economic status and security. An analysis of empirical material has shown that school subjective social status decreases more consistently among adolescent girls than among adolescent boys and Hispanics compared to other ethnic groups [2].

In foreign psychology, enough research is being carried out on the characteristics and interrelationships of the SSS with various personal aspects and aspects of the life of people of different ages and social backgrounds. In Russian psychological science, a small number of researchers are engaged in SSS research. For example, Zhuravlev A.L., Kupreychenko A.B. study SSS as a factor of self-determination and personality activity [27]; Balitskaya A.K., Vetokhina V.S., Merenkova I.A. believe that the SSS acts as an indicator of the security and goodwill of the world [28]; A.A. Zudina examines the differences in the dynamics of social status among unemployed people of different professions [29].

Attitudes and beliefs, psychological phenomena that are formed throughout the life of an individual under the influence of the social environment. They can be both unconscious and conscious, stable and unstable, but influencing behavior, assessment, choice and attitude to the surrounding reality, various situations, to the world and oneself.

Most social psychologists agree that attitudes are determined by value judgments about objects [30], but as Jonathan Potter, Alexa Hepburna, and Derek Edwardsb point out, research in this category has evolved without any systematic analysis of how value judgments are made in natural conditions [31]. The orthodox point of view is that attitudes are in people's heads and can only be deduced from their answers [30], which raises some questions about the accuracy of the research results.

\section{Materials and Methods}

The study involved 169 students aged 16 to 47 years $(\mathrm{M}=20.6, \mathrm{SD}=4.4(56.4 \% \mathrm{men})$ studying at different levels of education (bachelor's degree - 37.8\% $(\mathrm{M}=18.8, \mathrm{SD}=1.6$, 50.8 men), master's degree - 45.5\% $(\mathrm{M}=21.6, \mathrm{SD}=3.5,53.5 \mathrm{men})$, specialty (MAequivalent $)-16.7 \%(\mathrm{M}=22.3, \mathrm{SD}=8.1,76.9 \mathrm{men}))$. The following methods were used: semantic differential (adaptation of the V.M. Bekhterev Psychoneurological Institute); interview - World assumptions scale (WAS) R. Janoff-Bulman (adapted and restandardized by M.A. Padun, A.V. Kotelnikova), the method of diagnostics of socio- 
psychological attitudes of personality by O.F. Potemkina; statistical methods (descriptive statistics, Mann Whitney U test, Kruskal-Wallis test, Wilcoxon Rank- Sum Test, Spearman rank correlation coefficient).

The personality differential scales were filled out by the respondents with instructions to assess their real and ideal social status.

The purpose of the study was to study the characteristics of the subjective assessment of the social status and socio-psychological attitudes of student youth at different levels of education.

The tests were carried out on the assumptions that: 1) the subjective assessment of the real and ideal social status, as well as socio-psychological attitudes, may differ among students of different levels of education; 2) the real and ideal social status can be assessed in different ways by students of different levels of education; 3) there may be a relationship between socio-psychological attitudes and a subjective assessment of the real and ideal social status.

\section{Results}

The sample was divided into groups according to the educational levels of bachelors (hereinafter - BA), masters (hereinafter - $M A$ ), specialty students (hereinafter - MAequivalent). Testing the assumptions about differences in the subjective assessment of the real and ideal social status of the Kruskal-Wallis test among students of different levels of education did not show statistically significant differences (table 1). Therefore, further, a pairwise comparison of the Mann Whitney $U$ test groups was carried out (table 1).

Table 1. Subjective assessment of the real and ideal social status by students of different levels of education

\begin{tabular}{|c|c|c|c|c|c|c|c|}
\hline \multicolumn{2}{|c|}{ Group / Test scale } & $\begin{array}{c}\text { Factor } \\
\text { Evaluation } \\
\text { RSS }\end{array}$ & $\begin{array}{c}\text { Factor } \\
\text { Potency } \\
\text { RSS }\end{array}$ & $\begin{array}{c}\text { Factor } \\
\text { Activity } \\
\text { RSS }\end{array}$ & $\begin{array}{c}\text { Factor } \\
\text { Evaluation } \\
\text { ISS }\end{array}$ & $\begin{array}{c}\text { Factor } \\
\text { Potency } \\
\text { ISS }\end{array}$ & $\begin{array}{c}\text { Factor } \\
\text { Activity } \\
\text { ISS }\end{array}$ \\
\hline $\begin{array}{l}\text { Group } 1 \\
\text { (BA) }\end{array}$ & $\mathrm{n}=59$ & $\begin{aligned} M & =7.5, \\
\sigma & =8.7\end{aligned}$ & $\begin{array}{c}\mathrm{M}=4.7, \\
\sigma=8.5\end{array}$ & $\begin{array}{c}\mathrm{M}=2.4 \\
\sigma=7.1\end{array}$ & $\begin{array}{c}\mathrm{M}=10.3, \\
\sigma=7.8\end{array}$ & $\begin{aligned} M & =7.5, \\
\sigma & =6.8\end{aligned}$ & $\begin{aligned} \mathrm{M} & =5.4, \\
\sigma & =5.2\end{aligned}$ \\
\hline $\begin{array}{c}\text { Group } 2 \\
\text { (MA) }\end{array}$ & $n=71$ & $\begin{array}{l}M=7.3, \\
\sigma=7.95\end{array}$ & $\begin{aligned} M & =5.4, \\
\sigma & =7.9\end{aligned}$ & $\begin{array}{c}\mathrm{M}=3.5, \\
\sigma=6.8\end{array}$ & $\begin{aligned} M & =7.8, \\
\sigma & =9.7\end{aligned}$ & $\begin{array}{c}M=5.6, \\
\sigma=7.3\end{array}$ & $\begin{aligned} M & =3.3, \\
\sigma & =6.5\end{aligned}$ \\
\hline $\begin{array}{c}\text { Group } 3 \\
\text { (MA- } \\
\text { equivalent) }\end{array}$ & $n=26$ & $\begin{aligned} \mathrm{M} & =6.7, \\
\sigma & =9.2\end{aligned}$ & $\begin{array}{c}\mathrm{M}=6.5, \\
\sigma=7.8\end{array}$ & $\begin{array}{l}M=5.3, \\
\sigma=6.95\end{array}$ & $\begin{array}{c}\mathrm{M}=12.2, \\
\sigma=6.8\end{array}$ & $\begin{array}{c}\mathrm{M}=9.7 \\
\sigma=5.3\end{array}$ & $\begin{aligned} \mathrm{M} & =5.8, \\
\sigma & =4.1\end{aligned}$ \\
\hline \multicolumn{2}{|c|}{$\begin{array}{l}\text { Kruskal-Wallis } \\
\text { test }\end{array}$} & 0.187 & $\begin{array}{l}0.65 \\
8\end{array}$ & $\begin{array}{l}2.54 \\
2\end{array}$ & 4.869 & 6.198 & $\begin{array}{l}3.16 \\
4\end{array}$ \\
\hline \multicolumn{2}{|c|}{$\bar{p}$} & 0.911 & $\begin{array}{l}0.72 \\
0\end{array}$ & $\begin{array}{l}0.28 \\
1\end{array}$ & 0.088 & $\begin{array}{l}0.045 \\
*\end{array}$ & $\begin{array}{l}0.20 \\
6\end{array}$ \\
\hline \multicolumn{2}{|c|}{$\begin{array}{l}\text { Comparison } \\
\text { groups }\end{array}$} & - & - & - & $\begin{array}{l}\text { Group } \\
2-3\end{array}$ & $\begin{array}{l}\text { Group } \\
2-3\end{array}$ & - \\
\hline \multicolumn{2}{|c|}{$\begin{array}{l}\text { Mann Whitney } \\
\text { U test }\end{array}$} & - & - & - & 667.0 & 629.0 & - \\
\hline \multicolumn{2}{|c|}{ p } & - & - & - & $0.037^{*}$ & $\begin{array}{l}0.016 \\
* *\end{array}$ & - \\
\hline
\end{tabular}

Notes: RSS - real social status, ISS - ideal social status, ${ }^{* *}$ - significance level $0.01 ;^{*}$ significance level 0.05

It was established that factor Potency of the ideal social status among masters and specialists is significantly different, and there is also a tendency for differences in factor Evaluation of the ideal social status. 
Testing the hypothesis that real and ideal social status can be assessed differently by students of different levels of education, the Wilcoxon Rank-Sum Test showed statistically significant differences (table 2).

Table 2. Comparison of subjective assessments of real and ideal status

\begin{tabular}{|c|c|c|c|c|c|c|c|}
\hline \multicolumn{2}{|c|}{ Group / Test scale } & \multirow{2}{*}{$\begin{array}{c}\begin{array}{c}\text { Factor } \\
\text { Evaluation } \\
\text { RSS }\end{array} \\
M=7.5 \\
\sigma=8.7 \\
\end{array}$} & \multirow{2}{*}{$\begin{array}{c}\begin{array}{c}\text { Factor } \\
\text { Evaluation } \\
\text { ISS }\end{array} \\
M=10.3 \\
\sigma=7.8 \\
\end{array}$} & \multirow{2}{*}{$\begin{array}{c}\begin{array}{c}\text { Factor } \\
\text { Potency } \\
\text { RSS }\end{array} \\
M=4.7, \\
\sigma=8.5 \\
\end{array}$} & \multirow{2}{*}{$\begin{array}{c}\begin{array}{c}\text { Factor } \\
\text { Potency } \\
\text { ISS }\end{array} \\
M=7.5, \\
\sigma=6.8 \\
\end{array}$} & \multirow{2}{*}{$\begin{array}{c}\begin{array}{c}\text { Factor } \\
\text { Activity } \\
\text { RSS }\end{array} \\
M=2.4 \\
\sigma=7.1 \\
\end{array}$} & \multirow{2}{*}{$\begin{array}{c}\begin{array}{c}\text { Factor } \\
\text { Activity } \\
\text { ISS }\end{array} \\
\begin{array}{c}M=5.4, \\
\sigma=5.2\end{array}\end{array}$} \\
\hline $\begin{array}{l}\text { Group } 1 \\
(\mathrm{BA})\end{array}$ & $\mathrm{n}=59$ & & & & & & \\
\hline \multicolumn{2}{|c|}{$\begin{array}{c}\text { Wilcoxon Rank- } \\
\text { Sum Test } \\
\end{array}$} & \multicolumn{2}{|c|}{-2.379} & \multicolumn{2}{|c|}{-1.807} & \multicolumn{2}{|c|}{-2.730} \\
\hline \multicolumn{2}{|c|}{$\mathrm{p}$} & \multicolumn{2}{|c|}{$0.017 * *$} & \multicolumn{2}{|c|}{0.071} & \multicolumn{2}{|c|}{$0.006^{* *}$} \\
\hline $\begin{array}{c}\text { Group } 2 \\
\text { (MA) }\end{array}$ & $\mathrm{n}=71$ & $\begin{array}{l}M=7.3, \\
\sigma=7.95\end{array}$ & $\begin{array}{c}M=7.8 \\
\sigma=9.7\end{array}$ & $\begin{array}{c}M=5.4 \\
\sigma=7.9\end{array}$ & $\begin{array}{c}M=5.6 \\
\sigma=7.3\end{array}$ & $\begin{aligned} M & =3.5 \\
\sigma & =6.8\end{aligned}$ & $\begin{array}{c}M=3.3 \\
\sigma=6.5\end{array}$ \\
\hline \multicolumn{2}{|c|}{$\begin{array}{c}\text { Wilcoxon Rank- } \\
\text { Sum Test }\end{array}$} & \multicolumn{2}{|c|}{-1.388} & \multicolumn{2}{|c|}{-0.381} & \multicolumn{2}{|c|}{-0.249} \\
\hline \multicolumn{2}{|l|}{$\mathrm{p}$} & \multicolumn{2}{|c|}{0.165} & \multicolumn{2}{|c|}{0.703} & \multicolumn{2}{|c|}{0.804} \\
\hline $\begin{array}{c}\text { Group } 3 \\
\text { (MA- } \\
\text { equivalent) }\end{array}$ & $\mathrm{n}=26$ & $\begin{aligned} M & =6.7 \\
\sigma & =9.2\end{aligned}$ & $\begin{array}{c}M=12.2, \\
\sigma=6.8\end{array}$ & $\begin{array}{c}\mathrm{M}=6.5 \\
\sigma=7.8\end{array}$ & $\begin{aligned} M & =9.7 \\
\sigma & =5.3\end{aligned}$ & $\begin{array}{l}M=5.3, \\
\sigma=6.95\end{array}$ & $\begin{array}{c}M=5.8 \\
\sigma=4.1\end{array}$ \\
\hline \multicolumn{2}{|c|}{$\begin{array}{c}\text { Wilcoxon Rank- } \\
\text { Sum Test }\end{array}$} & \multicolumn{2}{|c|}{-3.260} & \multicolumn{2}{|c|}{-2.516} & \multicolumn{2}{|c|}{-0.321} \\
\hline \multicolumn{2}{|c|}{$\mathrm{p}$} & \multicolumn{2}{|c|}{$0.001 * *$} & \multicolumn{2}{|c|}{$0.012 * *$} & \multicolumn{2}{|c|}{.749} \\
\hline
\end{tabular}

Notes: RSS - real social status, ISS - ideal social status, ${ }^{* *}$ - significance level 0.01 ; ${ }^{*}$ significance level 0.05

Bachelors have excellent factor Evaluation and factor Activity of real and ideal social status. factor Evaluation and factor Activity of the ideal social status are of great importance. The masters did not reveal differences in subjective assessments of real and ideal social status. Students of the specialty(MA-equivalent) differ in factor Evaluation and factor Potency of real and ideal social status, where large values are also observed in the position of ideal social status.

Further, the assumption about the differences in the socio-psychological attitudes of students of different levels of education Kruskal-Wallis test was tested (table 3).

Table 3. Socio-psychological attitudes of students at different levels of education (only statistically significant results are given)

\begin{tabular}{|c|c|c|c|c|c|}
\hline \multicolumn{2}{|c|}{ Group / Test scale } & $\begin{array}{c}\text { Freedom } \\
\text { orientation }\end{array}$ & $\begin{array}{c}\text { The world is } \\
\text { benevolent }\end{array}$ & Fairness & $\begin{array}{c}\text { Belief about } \\
\text { control }\end{array}$ \\
\hline Group 1 (BA) & $\mathrm{n}=59$ & $\mathrm{M}=8.9, \sigma=12$ & $\mathrm{M}=5.9, \sigma=2.4$ & $\mathrm{M}=5.9, \sigma=2.4$ & $\mathrm{M}=6.8, \sigma=2.4$ \\
\hline Group 2 (MA) & $\mathrm{n}=71$ & $\mathrm{M}=5.9, \sigma=1.8$ & $\mathrm{M}=4.9, \sigma=2.4$ & $\mathrm{M}=4.9, \sigma=2.3$ & $\mathrm{M}=5.8, \sigma=2.2$ \\
\hline $\begin{array}{c}\text { Group 3 (MA- } \\
\text { equivalent) }\end{array}$ & $\mathrm{n}=26$ & $\mathrm{M}=6.8, \sigma=1.6$ & $\mathrm{M}=6.4, \sigma=2.3$ & $\mathrm{M}=6.3, \sigma=2.3$ & $\mathrm{M}=6.1, \sigma=2$ \\
\hline \multicolumn{2}{|c|}{$\begin{array}{c}\text { Kruskal-Wallis } \\
\text { test }\end{array}$} & 22.758 & 9.563 & 10.244 & 6.654 \\
\hline \multicolumn{2}{|c|}{$\mathrm{p}$} & $0.000^{* *}$ & $0.008^{* *}$ & $0.006^{* *}$ & $0.036^{*}$ \\
\hline
\end{tabular}

Notes: ** - significance level $0.01 ; *$ - significance level 0.05

It was found that students of different levels of education have different attitudes "reedom orientation", "the world is benevolent", "fairness" and "beliefs about control". Attitudes toward freedom and "beliefs about control" are more pronounced among bachelors, while "the world is benevolent" and "fairness" are more pronounced among specialists (MA-equivalent). Master's students ranked lower in all the settings presented. 
The Spearman rank correlation coefficient was tested for the hypothesis of the relationship between socio-psychological attitudes and the subjective assessment of real and ideal social status (table 4).

Table 4. Results of the correlation analysis of socio-psychological attitudes and subjective assessment of the real and ideal social status (only statistically significant results are given)

\begin{tabular}{|c|c|c|c|}
\hline \multicolumn{2}{|c|}{ Variables } & \multirow{2}{*}{$\begin{array}{c}\mathbf{r}- \\
\text { Spearman }\end{array}$} & \multirow{2}{*}{$\begin{array}{c}\text { p- } \\
\text { Value }\end{array}$} \\
\hline $\begin{array}{c}\text { Scales of subjective assessment of } \\
\text { social status }\end{array}$ & $\begin{array}{c}\text { Socio-psychological } \\
\text { attitudes }\end{array}$ & & \\
\hline \multirow{6}{*}{ Factor Evaluation RSS } & Result orientation & 0.204 & $0.011^{* *}$ \\
\hline & Altruism orientation & 0.163 & $0.042 *$ \\
\hline & $\begin{array}{l}\text { Self-interest } \\
\text { orientation }\end{array}$ & -0.187 & $0.020^{*}$ \\
\hline & The world is benevolent & 0.213 & $0.008^{* *}$ \\
\hline & Fairness & 0.242 & $0.002 * *$ \\
\hline & Self-image & 0.169 & $0.035^{*}$ \\
\hline \multirow{4}{*}{ Factor Activity RSS } & Result orientation & 0.318 & $0.000 * *$ \\
\hline & Work orientation & 0.195 & $0.015^{* *}$ \\
\hline & Power orientation & 0.260 & $0.001 * *$ \\
\hline & Fairness & 0.166 & $0.039 *$ \\
\hline \multirow{2}{*}{ Factor Evaluation ISS } & The world is benevolent & 0.248 & $0.002 * *$ \\
\hline & Fairness & 0.230 & $0.004 * *$ \\
\hline \multirow{4}{*}{ Factor Activity ISS } & Result orientation & 0.213 & $0.007 * *$ \\
\hline & Work orientation & 0.205 & $0.010^{* *}$ \\
\hline & The world is benevolent & 0.184 & $0.022 *$ \\
\hline & Fairness & 0.247 & $0.002 * *$ \\
\hline
\end{tabular}

Notes: RSS - real social status, ISS - ideal social status, ${ }^{* *}$ - significance level 0.01 ; ${ }^{*}$ significance level 0.05

A positive relationship was established between factor Evaluation of the real social status with the attitudes "result orientation", "altruism orientation", "the world is benevolent", "fairness", "self-image" and a negative connection with the "self-interest orientation (orientation toward egoism)" At the same time, an interesting fact is that factor Evaluation of the ideal social status has direct relationships only with the attitudes "the world is benevolent" and "fairness".

Factor Activity of the real social status is positively correlated with the attitudes "result orientation", "work orientation", "power orientation" and "fairness". At the same time, the activity of the ideal social status loses its relationship with the "power orientation" but the attitude "the world is benevolent" appears.

The power of real and ideal social status has no connections with socio-psychological attitudes.

\section{Discussion}

The results of the study of the subjective assessment of the social status and sociopsychological attitudes of students at different levels of education allow us to describe the quantitative characteristics of the subjective assessment of the real and ideal social status by students of different levels of education, as well as the relationship between sociopsychological attitudes and the semantic space of social status. 
The characteristics of the semantic space of real and ideal social status are not different when comparing bachelors, masters and specialty (MA-equivalent) students. However, the characteristics of the semantic space of the ideal status are different for masters and specialty (MA-equivalent) students. Namely, the factor Evaluation and factor Potency of the ideal social status differ. Specialist (MA-equivalent) students find ideal social status more attractive than graduate students. In the self-assessments of specialty (MA-equivalent) students, the ideal social status is characterized by a higher level of self-confidence, independence from external circumstances and assessments, and the belief in the availability of personal resources in coping with difficult life situations than among graduate students.

Comparison of the characteristics of the semantic space of real and ideal social status also showed a number of differences among students of different levels of education. Bachelors have different factor Evaluation and factor Activity in self-assessment of real and ideal social status. Ideal status is endowed in this group with both greater attractiveness, stability, and a higher level of activity, sociability, impulsivity. Specialist (MA-equivalent) students have different self-assessments of factor Evaluation and factor Potency of real and ideal social status. Ideal social status is also endowed with great expectations in this group. The ideal social status, according to the students of the specialty (MA-equivalent), is more attractive than the one currently available, and is also endowed with greater confidence, independence, and resilience. Master's students showed no differences in self-assessments of their real and ideal social status. It should be noted that undergraduates have lower values of factor Evaluation, factor Potency and factor Activity, both real and ideal social status, in comparison with other groups. These results suggest that graduate students have a greater degree of awareness in the subjective assessment of their social status; in this group, ideas about their future social status are more realistic. Bachelors and specialty (MAequivalent) students tend to idealize the future social status, endow it with great potential, without taking into account real opportunities and situations. An overestimated level of claims regarding the future social status can further lead to the experience of unhappiness in a situation when expectations do not correspond to the real state of affairs.

A similar picture in the severity of indicators is observed in the analysis of social and psychological attitudes. The attitudes "Freedom orientation", "the world is benevolent", "fairness" and "beliefs about control" were statistically different, so the description will only concern these scales. Bachelors, to a greater extent than other groups, have a pronounced orientation towards freedom, the conviction of the ability to control the world around them and its events. In our opinion, these attitudes can be both contradictory and cause internal conflict, and provide greater flexibility in behavior, provided that the dominant attitude is chosen in a particular situation. Specialist (MA-equivalent) students have a more pronounced orientation towards the benevolence of the world and its fairness. Master's students have lower scores for the above-mentioned attitudes, in comparison with other groups.

Research into the relationship between parental attitudes toward control and the social status of schoolchildren and students has shown that adolescents who are not yet students view emerging adult life as a focus on others and consider themselves adults. First and secondary students perceive their age as unstable and intermediate feelings, consider themselves adults only in certain aspects. In addition, the relationships were established between the controlling behavior of parents and the formation of a sense of autonomy and self-sufficiency in adolescents and students. Adrijana Berčić, Inja Erceg found that parental behavior characterized by high involvement, the manifestation of care and love, adequate control does not undermine the autonomy of children, does not cause destructive effects, like other types of parental control [32]. 
Studying the relationship between the subjective socio-economic status of families and life satisfaction among adolescents by scientists Yan Wenjing, Yang Kairong, Wang Qiuling established close correlations, as well as factors mediating on them: self-esteem and social support [7]. These results provide an indirect confirmation that the attitude towards "the world is benevolent" and "the self-image" can be predictors of the formation of a subjective assessment of social status in children and young people.

The description of the relationship between the characteristics of the semantic space of social status and socio-psychological attitudes is interesting in comparing the real and ideal social status of student youth. First, it should be noted that factor Potency of the real and ideal social status has no significant connections with attitudes. That is, the characteristics of social status such as self-confidence, independence and the ability to cope with difficult life situations are not associated with diagnosed attitudes. A high assessment of the attractiveness of real social status presupposes high values of orientation towards results, altruism, belief in benevolence and justice in the world, and low values of orientation towards selfishness. At the same time, a high assessment of the ideal social status is associated only with belief in the benevolence and justice of the world. That is, the assessment of the desired social status is not associated with more instrumental attitudes and is based on basic beliefs about the benevolence of the surrounding world. However, in the works of V.I. Pishchik, who studies the values of student youth and mature people through actual fears: I, others, nature, culture, technology, mystical, the presence of other dominant attitudes is shown. She found that among people of mature age with a stable assessment of their subjective status, the value of culture and the fear of its loss prevail, among students (masters and graduate students) the value of the self and the fear of losing oneself dominate, among college students and bachelors of the 1st and 2nd year of age, information is most valuable. technology and actualized fear of multiple worlds [25]. These data allow us to note that the issue of attitudes about the goodwill of the world, the environment and trust requires further study.

High assessments of the activity, sociability and impulsiveness of the real social status suggest that Russian youth have a pronounced orientation towards results, work, power and faith in the justice of the world. In foreign studies of people of different status, age and position in society, various results of the study of attitudes towards work and activity are described. Studies by Grover Naveen, Jameel Sayma, Dhiman Vishal have shown that there are minor changes in attitudes towards work and towards patients in medical college students during their professional practice in a psychiatric clinic. The authors conclude that a temporary change in professional status has led to positive shifts in attitudes towards patients with mental disorders and psychiatry [33]. Excessive employment and unemployment also have a relationship with status assessments and socio-psychological attitudes. For example, Yashuo Chen, Pengbo Li, Chunjiang Yang found a negative relationship between overtime work and subjective social status, and clarify that this relationship was stronger with a low level of fairness than with a high level of fairness [15]. In a study of the SSS of temporarily unemployed people, Neubert Marie, Suessenbach Philipp, Rief Winfried found that unemployment is associated with lower social status and worsening mental health. In addition, the researchers found that the status of others in society is perceived by the subjects through the status of employment, profession and mental health [5].

Self-assessment of the ideal social status of students has similar interrelationships as the assessment of real status. However, in the course of the study, it was found that the orientation toward power is replaced in this position by belief in the benevolence of the world. That is, the assessment of the activity of the ideal social status, in contrast to the real status, is focused not on managing people, but on a more abstract basic belief about the benevolence of the world. The studies by Wingen Tobias, Englich Birte, Estal-Munoz 
Victor show that social class is significantly correlated with such aspects of quality of life as physical, mental, social and environmental. The authors emphasize that it is the social status of the individual, that is, respect in the eyes of others, that is the mediating factor of these positive aspects, and not the power [34].

\section{Conclusions}

The results of the study of the subjective assessment of the social status and sociopsychological attitudes of student youth allowed us to draw the following conclusions.

Master's students have a greater degree of awareness in the subjective assessment of their social status; in this group, ideas about the future social status are more realistic. Bachelors and specialty (MA-equivalent) students tend to idealize the future social status, endow it with great potential, without taking into account real opportunities and situations.

Bachelors, to a greater extent than other groups, have a pronounced orientation towards freedom, the conviction of the ability to control the world around them and its events. Specialist (MA-equivalent) students have a more pronounced orientation towards the benevolence of the world and its fairness. Master's students do not have lower values for all diagnosed installations.

Only factor Evaluation and factor Activity of real and ideal social status has an interconnection with socio-psychological attitudes. The interrelationships between the assessment of real and ideal social status indicate a great idealization and abstractness of the latter. While factor Activity of both real and ideal social status has connections with instrumental and abstract attitudes, the position of ideal social status "loses" its connection with the attitude toward power.

Research prospects are aimed at studying the substantive characteristics of the subjective assessment of the real and ideal social status of student youth, studying the factor structure of the characteristics of the semantic field of self-assessment of social status and socio-psychological attitudes.

\section{References}

1. C. Yunsong, F. Xiaoguang, Social sciences in china, 3, 70-88 (2019) https://doi.org/10.1080/02529203.2019.1595063

2. D. Rahal, V. Huynh, S. Cole, Developmental psychology, 6, 1220-1232 (2020) https://doi.org/10.1037/dev0000919

3. S. P. Bach, P. P. Hogh, A. J. Hviid, et al. Bmc public health bmc Public Health, 20, 396 (2020) https://doi.org/10.1186/s12889-020-08509-8

4. M. A. Russell, C. L. Odgers, Research on Adolescents, S2, 532-544 (2020) https://doi.org/10.1111/jora.12496

5. M. Neubert, P. Suessenbach, W. Rief, et al., Psychology research and behavior management, 12, 557-564 (2019) DOI: 10.2147/PRBM.S207971

6. D. Rahal, J. J. Chiang, Melissa Fales, et al. Psychology \& health may (2020) https://doi.org/10.1080/08870446.2020.1761977

7. W. Yan, K. Yang, Q. Wang, et al. Youth \& society,unsp 0044118X20941344, JUL (2020) https://doi.org/10.1177/0044118X20941344

8. E. Loeb, N. M. Hurd, Journal of college student retention-research theory \& practice, 2, 150-165 (2019) https://doi.org/10.1177/1521025117696821

9. A. L. Roy, A. Isaia, C. P., Li-Grining, Journal of family psychology, 2, 240-245 (2019) https://doi.org/10.1037/fam0000487 
10. M. I.Cardel, S. Tong, G. Pavela, E. Dhurandhar, D. Miller, R. Boles, OBESITY, 12, 1923-1930 (2018) https://doi.org/10.1002/oby.22439

11. J. E. Uecker, Society and mental health, unsp 2156869319869401 (2019) https://doi.org/10.1177/2156869319869401

12. O. Sahin, S. Nasir, Journal of economy culture and society, 59, 185-198 (2019) DOI: 10.26650/JECS2018-0013,

https://cdn.istanbul.edu.tr/file/1CD58DF90A/4A7D9B0CF598461E8AB2CBD7C94E7 5FE?doi $=10.26650 / \mathrm{JECS} 2018-0013$

13. B. C. Meskhi, S. V. Ponomareva, E. A. Ugnich, M. G. Drozd, Lecture Notes in Networks and Systems (see books), 129, 826-834 (2020) DOI: 10.1007/978-3-03047945-9_88 https://www.elibrary.ru/item.asp?id=43300876

14. E. Suroedova, Y. Tushnova, E. Belousova, E3S Web of Conferences, 175, 15028 (2020) DOI https://doi.org/10.1051/e3sconf/202017515028

15. Y. Chen, P. Li, C. Yang, International journal of environmental RESEARCH AND PUBLIC HEALTH, 9, 3265 (2020) DOI 10.3390/ijerph17093265

16. F. Euteneuer, S. J. Schaefer, M. Neubert, et al. STRESS AND HEALTH, 5, 675-680 (2019) https://doi.org/10.1002/smi.2892

17. K. Clements-Nolle, R. Oman, Y. Yang, et al., Journal of Interpersonal Violence, 2, S97-S97 (2020) https://doi.org/10.1177/0886260519900976

18. D. Amir, C. Valeggia, M. Srinivasan, et al., PLOS ONE, 12, e0226550 (2019) https://doi.org/10.1371/journal.pone.0226550

19. W. de A. Ferreira, L. Giatti, R. Carvalho de Figueiredo, et al., CIENCIA \& SAUDE COLETIVA, 4, 1267-1280 (2018) DOI: 10.1590/1413-81232018234.16972016

20. Y. Mi Cheon, P. S. Ip, M. Haskin, et al., FRONTIERS IN PSYCHOLOGY, 11, 959 (2020) DOI: 10.3389 / fpsyg.2020.00959

21. I. E. Castro, B. Hruska, B. B. GumpRace, JOURNAL OF RACIAL AND ETHNIC HEALTH DISPARITIES (2020) https://doi.org/10.1007/s40615-020-00707-9

22. S. Yu, S. L. Blader, PERSONALITY AND SOCIAL PSYCHOLOGY BULLETIN, 3, 331-348 (2020) https://doi.org/10.1177/0146167219853841

23. N. N. Mozgovaya, E. A. Suroedova, International Journal of Cognitive Research in Science, Engineering and Education, 2, 71-77 (2013) https://elibrary.ru/item.asp?id=24330956

24. O. Nikolenko, L. Zheldochenko, N. Lomova, 175, 15029 (2020) DOI: https://doi.org/10.1051/e3sconf/202017515029

25. V. I. Pishchik, Social psychology and society, 2, 67-81 (2019) DOI: 10.17759/sps.2019100206

26. N. F. Efremova, Russian psychological journal, 2, 227-244 (2017) DOI: 10.21702/rpj.2017.2.13

27. A. L. Zhuravlev, A. B. Kupreychenko, Psychology of education: childhood as a strategic resource for the development of society, 113-118 (2011) https://elibrary.ru/item.asp?id=23107954 (Last accessed 22.06.2020)

28. A. K. Balitskaya, V. S. Vetokhina, I. A. Merenkova, Social and Personal Security and Human Protection, 5-10 (2015) https://elibrary.ru/item.asp?id=28287351 (Last accessed 22.06.2020)

29. A. A. Zudina, World of Russia. Sociology. Ethnology, 4, .154-184 (2016) https://elibrary.ru/item.asp?id=27021678 (Last accessed 22.06.2020) 
30. G. R. Maio, G. Haddock, B. Verplanken. The psychology of attitudes and attitude change, (2019).

31. A. Hepburna, D. Edwa, FNNrdsb, Qualitative research in psychology, 3, 336-356 (2020) https://doi.org/10.1080/14780887.2020.1725952

32. A. Berčić, I. Erceg, Primenjena psihologija, 3, 305-326 (2019) doi: 10.19090/pp.2019.3.305-326

33. N. Grover, S. Jameel, V. Dhiman, Indian journal of psychology medicine, 5, 462-465 (2019) DOI: 10.4103/IJPSYM.IJPSYM_342_18

34. T. Wingen, B. Englich, V. Estal-Munoz, et al., Applied Research in Quality of Life? (2020) https://doi.org/10.1007/s11482-020-09853-y 